\title{
Host-related Morphological Variation of Dwellings Inhabited by the Crab Domecia acanthophora in the Corals Acropora palmata and Millepora complanata (Southern Caribbean)
}

\author{
Bert W. Hoeksema ${ }^{1,2,3, *([)}$ and Jaaziel E. García-Hernández ${ }^{4}(\mathbb{D}$ \\ 1 Taxonomy and Systematics Group, Naturalis Biodiversity Center, 2300 RA Leiden, The Netherlands \\ 2 Groningen Institute for Evolutionary Life Sciences, University of Groningen, \\ 9700 CC Groningen, The Netherlands \\ 3 Institute of Biology Leiden, Leiden University, 2300 RA Leiden, The Netherlands \\ 4 Marine Genomic Biodiversity Laboratory, University of Puerto Rico-Mayagüez, La Parguera, PR 00667, USA; \\ jaaziel.garcia@upr.edu \\ * Correspondence: bert.hoeksema@naturalis.nl; Tel.: +31-717-519-6311
}

Received: 21 March 2020; Accepted: 3 April 2020; Published: 5 April 2020

Brachyuran crabs of various families are known as obligate associates of stony corals, with many of these species living as endosymbionts inside the skeleton of their hosts [1]. In particular, coral gall crabs (Cryptochiridae) have been well studied in tropical coral reefs around the world. These crabs can be recognized by the shape of their dwellings (or pits), which may be crescent-shaped or resemble a slit, a canopy, a basket, or a gall, depending on the identity and morphology of their host, and on the position inside the host's skeleton [2-7]. Cryptochirids are each known to be associated with a few scleractinian host species (Anthozoa: Scleractinia) or only one [2-7]. Crabs of the species Latopilumnus tubicolus Türkay and Schuhmacher, 1985 (Pilumnidae), have so far only been reported as endosymbionts of the Indo-Pacific scleractinian Tubastraea micranthus (Ehrenberg, 1834) [8]. Their dwellings are unique because they start in one of the coral's calyces from where they penetrate deep inside the coral branches [8], becoming long and tubular, whereas the pits (or cysts) of cryptochirids remain relatively shallow [2-7].

Other records of crabs living inside stony corals, concern unidentified species of the genera Tetralia Dana, 1851 (Tetraliidae) and Cymo De Haan, 1833 (Xanthidae) that live in association with Indo-Pacific Acropora spp. [9]. The pits constructed by Cymo sp. show an oval margin that becomes increasingly thick, resembling a collar on top of flattened, fused Acropora branches, whereas those of Tetralia sp. resemble a slit in between bifurcating, round Acropora branches, which eventually develop into galls [9]. Dwellings made by Atlantic Platypodiella spp. (Xanthidae) are usually oval but can start as shallow depressions inside hosts of the genus Palythoa (Anthozoa: Zoantharia) $[10,11]$, which are encrusting, colonial sea anemones related to scleractinians; they are leathery in appearance with sand particles inside their tissue instead of a calcareous skeleton.

The pits made by Cymo sp. resemble most those of the Atlantic crab Domecia acanthophora (Desbonne and Schramm, 1867) (Domeciidae) in flat branches of the scleractinian Acropora palmata (Lamarck, 1816) observed at Puerto Rico (Greater Antilles) and Venezuela (Southern Caribbean) [12,13]. Here, the same crab was also found in Acropora cervicornis (Lamarck, 1816) and Acropora prolifera (Lamarck, 1816), while it was also observed wandering on corals of other species [12,13]. Domecia acanthophora has also been reported as associated fauna of fire corals, like Millepora alcicornis Linneaus, 1758 at Brazil [14] and Millepora spp, at Yucatán, México [15]. However, no information is available on the morphology of Domecia pits in Millepora and its possible difference with Acropora. Therefore, we present information on Domecia dwellings found in six corals of A. palmata at Curaçao ( $<2 \mathrm{~m}$ depth; 
2015) and two corals of Millepora complanata Lamarck, 1816 at Klein Bonaire (2-3 m depth; 2019). Curaçao and Bonaire (next to Klein Bonaire) are major Dutch Caribbean islands, situated $50 \mathrm{~km}$ apart and $70-80 \mathrm{~km}$ off the coast of Venezuela. The observations were made during biodiversity surveys down to $30 \mathrm{~m}$ depth using the roving diving technique.

The Domecia pits in A. palmata were up to $2 \mathrm{~cm}$ long (Figure 1). Those at the margins of coral branches had outlines that were not fully closed (Figure 1d,e), whereas pits away from the margins were enclosed and showed a thickened, smooth periphery, like a collar around an open callus (Figure 1h-i). An intermediate form consisted of a fully enclosed pit without a thickened margin (Figure 1f). The crabs could still be observed when they were inside the dwelling (Figure $1 \mathrm{~d}-\mathrm{i}$ ) and also could easily be collected from an incomplete pit at a branch margin (Figure 1b).

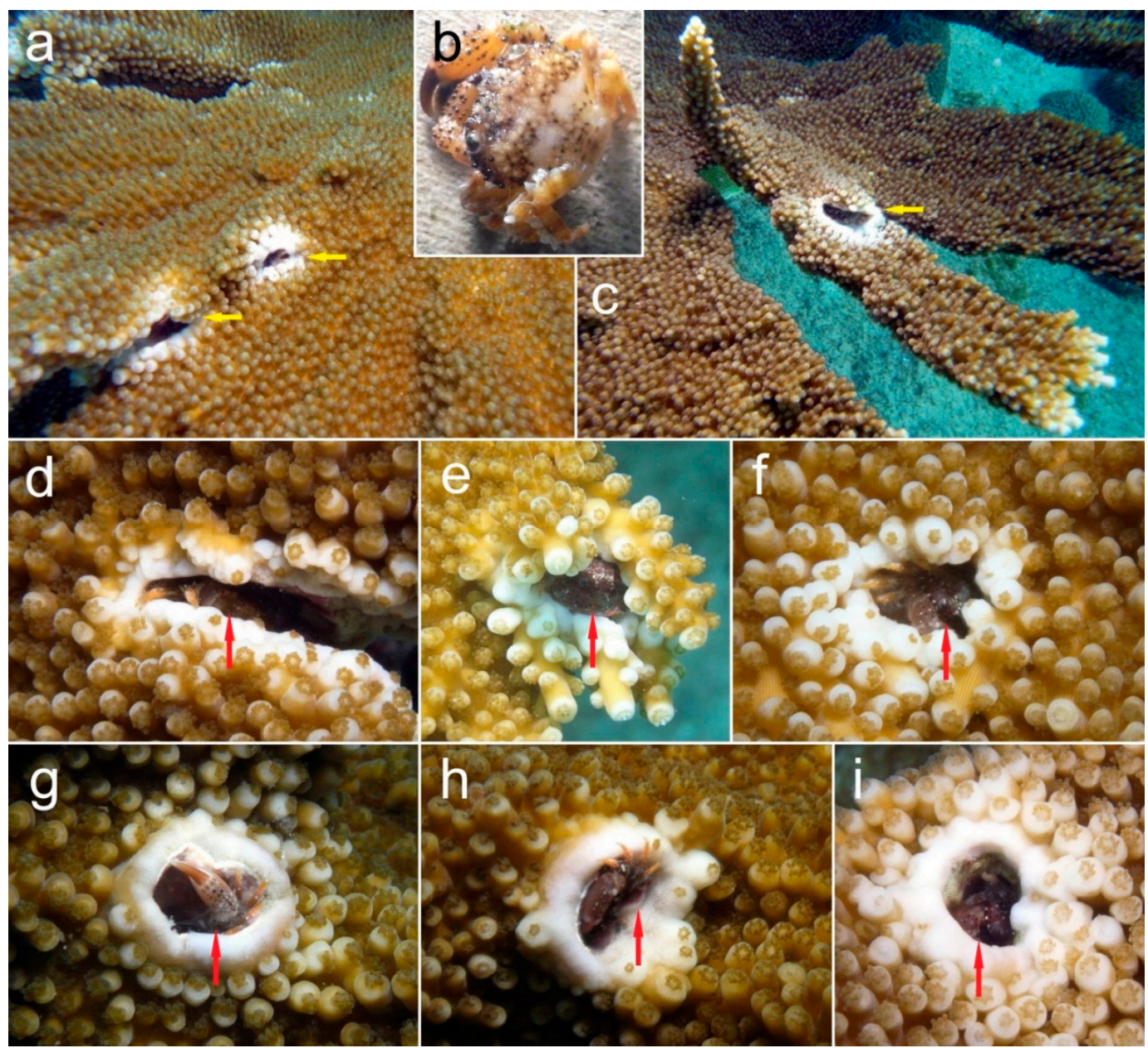

Figure 1. Acropora palmata at <2 m depth, Blue Wall dive site (2015), Curaçao $\left(12^{\circ} 08^{\prime} 06^{\prime \prime} \mathrm{N}, 68^{\circ} 59^{\prime} 16^{\prime \prime}\right.$ W), hosting Domecia acanthophora: (a,c) branches with crab pits; (b) a crab taken from a pit; (d-e) crab dwellings at the margin of a coral branch; and (f-i) crab pits away from the branch margin, showing a white collar. Yellow arrows: crab dwellings; red arrows: Crabs.

The Domecia dwellings in M. complanata were different in shape, usually consisting of folds in the coral's branches (Figure 2). They were most easily observed at the upper margins of the coral's vertical plates (Figure 2d-f) and did not show a collar-like thickening at the margin. Some dwellings occurred at a side of a plate (Figure 2b). One crab was found inside a narrow crevice (Figure 2c). In all cases, the crabs were easy to spot (Figure 2c-f). Interestingly, this association was only observed in exposed reef habitats at Klein Bonaire. It seemed that the crabs altered the shape of some of the Millepora corals by giving their branches a more contorted appearance (Figure 2b). Alternatively, the particular form of $M$. 
complanata inhabited by Domecia may also be a result of environmental factors (surge, currents, and turbulence) to which these organisms are exposed at Klein Bonaire.

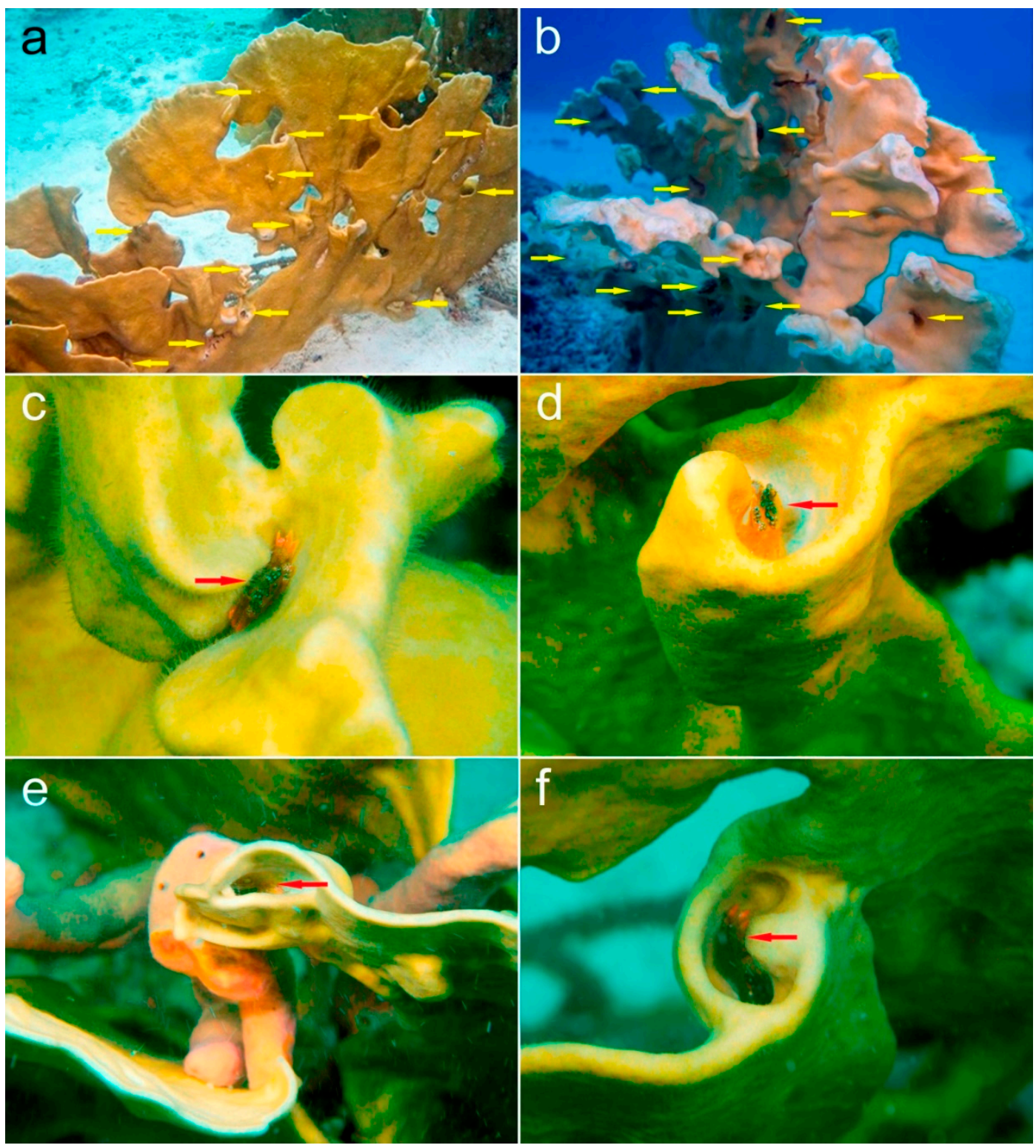

Figure 2. Millepora complanata at 2-3 m depth, Klein Bonaire (2019), hosting Domecia acanthophora: (a,c-f) Carl's Hill dive site $\left(12^{\circ} 09^{\prime} 53^{\prime \prime} \mathrm{N} 68^{\circ} 19^{\prime} 23^{\prime \prime} \mathrm{W}\right)$; (b) Monte's Divi dive site $\left(12^{\circ} 09^{\prime} 01^{\prime \prime} \mathrm{N}\right.$ $\left.68^{\circ} 18^{\prime} 55^{\prime \prime} \mathrm{W}\right)$; (c) crab inside narrow crevice; and (d-f) crabs inside pits consisting of folds at the upper margin of foliaceous coral branches. Yellow arrows: crab dwellings; red arrows: crabs.

The present information may facilitate recognition of endosymbiotic crab fauna in Acropora and Millepora corals, including fossil ones [4]. Further studies are required to determine whether Atlantic Domecia crabs associated with different hosts all belong to D. acanthophora or, alternatively, represent distinct but closely related species.

Author Contributions: Conceptualization and supervision, B.W.H.; methodology, illustrations and funding acquisition, B.W.H. and J.E.G.-H.; writing—original draft preparation, B.W.H.; writing—review and editing, B.W.H. and J.E.G.-H. All authors have read and agreed to the published version of the manuscript.

Funding: Fieldwork at Bonaire was supported by the WWF Netherlands Biodiversity Fund and the Treub Maatschappij - Society for the Advancement of Research in the Tropics. 
Acknowledgments: We thank staff of CARMABI (Curaçao) for hospitality. The Dive Shop (Curaçao), STINAPA, DCNA and Dive Friends (Bonaire) provided logistic support. Werner de Gier (Naturalis Biodiversity Center) assisted during the field work at Klein Bonaire. We are grateful to three anonymous reviewers for their helpful comments.

Conflicts of Interest: The authors declare no conflict of interest. The funders had no role in the design of the study; in the collection, analyses, or interpretation of data; in the writing of the manuscript, or in the decision to publish the results.

\section{References}

1. Castro, P. Brachyuran crabs symbiotic with scleractinian corals: A review of their biology. Micronesica 1976, $12,99-110$.

2. van der Meij, S.E.T. Host species, range extensions, and an observation of the mating system of Atlantic shallow-water gall crabs (Decapoda: Cryptochiridae). Bull. Mar. Sci. 2014, 90, 1001-1010. [CrossRef]

3. van der Meij, S.E.T.; Fransen, C.H.J.M.; Pasman, L.R.; Hoeksema, B.W. Phylogenetic ecology of gall crabs (Cryptochiridae) as associates of mushroom corals (Fungiidae). Ecol. Evol. 2015, 5, 5770-5780. [CrossRef] [PubMed]

4. Klompmaker, A.A.; Portell, R.W.; van der Meij, S.E.T. Trace fossil evidence of coral-inhabiting crabs (Cryptochiridae) and its implications for growth and paleobiogeography. Sci. Rep. 2016, 6, 23443. [CrossRef] [PubMed]

5. Hoeksema, B.W.; Butôt, R.; García-Hernández, J.E. A new host and range record for the gall crab Fungicola fagei as symbiont of the mushroom coral Lobactis scutaria at Hawai'i. Pac. Sci. 2018, 72, 251-261. [CrossRef]

6. Mohammed, T.A.A.; Yassien, M.H. Assemblages of two gall crabs within coral species northern Red Sea, Egypt. Asian J. Sci. Res. 2013, 6, 98-106. [CrossRef]

7. Terrana, L.; Caulier, G.; Todinanahary, G.; Lepoint, G.; Eeckhaut, I. Characteristics of the infestation of Seriatopora corals by the coral gall crab Hapalocarcinus marsupialis Stimpson, 1859 on the Great Reef of Toliara, Madagascar. Symbiosis 2016, 69, 113-122. [CrossRef]

8. Schuhmacher, H. The dwelling cavity of the coral crab Latopilumnus tubicolus (Crustacea, Pilumnidae) in Tubastraea micranthus (Scleractinia, Dendrophylliidae). Symbiosis 1987, 4, 289-302.

9. Eldredge, L.G.; Kropp, R.K. Decapod Crustacean-Induced Skeletal Modification in Acropora; FAO: Rome, Italy, 1981; Volume 2, pp. 115-119.

10. den Hartog, J.C.; Türkay, M. Platypodiella georgei spec. nov. (Brachyura: Xanthidae), a new crab from the island of St. Helena, South Atlantic Ocean, with notes on the genus Platypodiella Guinot, 1967. Zool. Meded. 1991, 65, 209-220.

11. García-Hernández, J.E.; Reimer, J.D.; Hoeksema, B.W. Sponges hosting the Zoantharia-associated crab Platypodiella spectabilis at St. Eustatius, Dutch Caribbean. Coral Reefs 2016, 35, 209. [CrossRef]

12. Patton, W.K. Studies on Domecia acanthophora, a commensal crab from Puerto Rico, with particular reference to modifications of the coral host and feeding habits. Biol. Bull. 1976, 132, 56-67. [CrossRef]

13. Grajal, P.A.; Laughlin, G.R. Decapod crustaceans inhabiting live and dead colonies of three species of Acropora in the Roques Archipelago, Venezuela. Bijdr. Dierk. 1984, 54, 220-230. [CrossRef]

14. Garcia, T.M.; Matthews-Cascon, H.; Franklin-Junior, W. Macrofauna associated with branching fire coral Millepora alcicornis (Cnidaria: Hydrozoa). Thalassas 2008, 24, 11-19.

15. González-Gómez, R.; Briones-Fourzán, P.; Álvarez-Filip, L.; Lozano-Álvarez, E. Diversity and abundance of conspicuous macrocrustaceans on coral reefs differing in level of degradation. PeerJ 2018, 6, e4922. 